Article

\title{
Antibiofilm Activity of Epoxy/Ag-TiO 2 Polymer Nanocomposite Coatings against Staphylococcus Aureus and Escherichia Coli
}

\author{
Santhosh S. M. and Kandasamy Natarajan * \\ Applied Polymer Materials Laboratory, Department of Chemistry, R. V. College of Engineering, \\ Mysore Road, Bangalore 560059, India; E-Mail: santhosh.s.m.rao@gmail.com \\ * Author to whom correspondence should be addressed; E-Mail: knatarajan.rvce@gmail.com; \\ Tel.: +91-80-6717-8038; Fax: +91-80-2860-0337.
}

Academic Editor: Anibal Maury-Ramirez

Received: 31 December 2014 / Accepted: 7 April 2015 / Published: 14 April 2015

\begin{abstract}
Dispersion of functional inorganic nano-fillers like $\mathrm{TiO}_{2}$ within polymer matrix is known to impart excellent photobactericidal activity to the composite. Epoxy resin systems with $\mathrm{Ag}^{+}$ion doped $\mathrm{TiO}_{2}$ can have combination of excellent biocidal characteristics of silver and the photocatalytic properties of $\mathrm{TiO}_{2}$. The inorganic antimicrobial incorporation into an epoxy polymeric matrix was achieved by sonicating laboratory-made nano-scale anatase $\mathrm{TiO}_{2}$ and $\mathrm{Ag}-\mathrm{TiO}_{2}$ into the industrial grade epoxy resin. The resulting epoxy composite had ratios of $0.5-2.0 \mathrm{wt} \%$ of nano-filler content. The process of dispersion of $\mathrm{Ag}-\mathrm{TiO}_{2}$ in the epoxy resin resulted in concomitant in situ synthesis of silver nanoparticles due to photoreduction of $\mathrm{Ag}^{+}$ion. The composite materials were characterized by DSC and SEM. The glass transition temperature $\left(T_{\mathrm{g}}\right)$ increased with the incorporation of the nanofillers over the neat polymer. The materials synthesized were coated on glass petri dish. Anti-biofilm property of coated material due to combined release of biocide, and photocatalytic activity under static conditions in petri dish was evaluated against Staphylococcus aureus ATCC6538 and Escherichia coli K-12 under UV irradiation using a crystal violet binding assay. Prepared composite showed significant inhibition of biofilm development in both the organisms. Our studies indicate that the effective dispersion and optimal release of biocidal agents was responsible for anti-biofilm activity of the surface. The reported thermoset coating materials can be used as bactericidal surfaces either in industrial or healthcare settings to reduce the microbial loads.
\end{abstract}


Keywords: epoxy nanocomposite; $\mathrm{Ag}-\mathrm{TiO}_{2}$ nanoparticles; photobactericidal; antibiofilm acitivity; crystal violet assay

\section{Introduction}

Biofilms are defined as communities of microorganisms that are developed on material surfaces. Prevention of microbial biofilm formation over the surface of materials is a technological imperative in health care. Many bacteria capable of forming biofilms on abiotic surfaces are menacing problems in medical and industrial systems. The biofilm forming ability of the opportunistic human pathogens Staphylococcus aureus and Escherichia coli, is a crucial step for sustenance and growth in above said environments [1]. Biofilms are a major source of biofouling in industrial water systems, and biofilm based industrial slimes also pose major problems for various industrial processes. Biofilm forming microbial cells attached to any surface in a moist environment can survive and proliferate. Pathogenic and resilient biofilms are difficult to eradicate with conventional disinfectants [2]. The interest in inorganic disinfectants such as metal oxide nanoparticles (NPs) is increasing. In the last decade, many studies describing the photocatalytic inactivation of bacteria using doped and undoped $\mathrm{TiO}_{2}$ coated on different substrates have been reported, including silver doped $\mathrm{TiO}_{2}$ [3-6]. A majority of these articles is focused on powder materials and thin films of $\mathrm{TiO}_{2}$ or doped $\mathrm{TiO}_{2}$. Unfortunately, most bare $\mathrm{TiO}_{2}$ coated films lose their efficiency of photocatalysis due to mass transfer [7,8]. However, only a fraction of studies deal with stemming of mass transfer of immobilized $\mathrm{TiO}_{2}$ or doped- $\mathrm{TiO}_{2}$ photocatalyst films. The most promising approach to overcome this disadvantage is by immobilization of $\mathrm{TiO}_{2}$ in the porous polymer matrix such as epoxides, the most important classes of compounds used in the coating industry. These epoxy composites provide thin-layer durable coatings having mechanical strength and good adhesion to a variety of substrates [9]. Antimicrobial epoxy based surface coatings of walls and floors can fight the nosocomial menace [10] in hospitals.

The antibacterial function of a $\mathrm{TiO}_{2}$ photocatalyst is markedly enhanced even with weak UV light, such as fluorescent lamps and with the aid of either silver or copper, which is harmless to the human body [11]. $\mathrm{TiO}_{2}$ nano-fillers improve mechanical properties like crack resistance, surface characteristics and can also contribute to the photostability of the host material. The photostability and photocatalytic activity of epoxy/nano- $\mathrm{TiO}_{2}$ coatings under UV irradiation has been reported by Calza et al. [12]. While doping $\mathrm{TiO}_{2}$ with silver can synergistically enhance photobactericidal acitivity of $\mathrm{TiO}_{2}$, a considerable improvement in mechanical properties can also be achieved by introducing very low amount of nano-fillers into resin system [13]. In addition, photo-stability of epoxy resin can be improved by the presence of nano- $\mathrm{TiO}_{2}$ by its UV absorption properties [14]. Thus, modification of polymers with $\mathrm{TiO}_{2}$ and subsequent coupling with $\mathrm{Ag}^{+} / \mathrm{Ag} \mathrm{NP}$ enhance the photocatalytic and antimicrobial property of the material. Nanoparticles are generally introduced into epoxy matrix using various approaches like, in situ synthesis by reacting the precursors or physical dispersion of pretreated nano-fillers by mechanical stirring and subsequently processed by ultrasonication $[15,16]$. Successful dispersion of nanoparticles within the polymer matrix is determined by factors like particle size, particle modifications, specific surface area, particle load and the particle morphology. 
Broadly there are two methods to impregnate a biocidal agent in order to achieve antibacterial polymeric materials. That is, either by introduction of aleaching biocidal agent into the polymer to form a composite or by covalent functionalization of the polymer with the pendent groups that confer antimicrobial activity. Such materials have displayed potent and broad spectrum antimicrobial activity [17]. The polycaprolactone-titania nanocomposites have been shown to decrease surface colonization of Escherichia coli and Staphylococcus aureus [18]. Similarly, introduction of (+)usnic acid, a natural antimicrobial agent into modified polyurethane prevented biofilm formation on the polymer surface by Staphylococcus aureus and Pseudomonas aeruginosa [19]. The poly(ethylene terephthalate) (PET) was surface functionalized with pyridinium groups possessing antibacterial properties, as shown by their effect on Escherichia coli [20]. Highly potent antibacterial activity toward both Gram-positive and Gram-negative bacteria was demonstrated by composites consisting of a cationic polymer matrix and embedded silver bromide nanoparticles [21].

There are very few empirical reports that quantitatively assess inhibition of biofilm formation on polymer surfaces by employing indicator dyes (crystal violet/fluorescent dye). Crystal violet (hexamethyl pararosaniline chloride) is such a dye, which binds proportionately to the peptidogly and can be a component of bacterial cell walls. It has been used by Kwasny and Opperman [22] to evaluate the amount of biofilm formed by staining the thick peptidoglycan layer of Gram-positive bacteria, the thin peptidoglycan layer of Gram-negative bacteria. In this study, anti-biofilm activity of polymeric surfaces was measured by protocol adoption as described by Kwasny and Opperman with minor modifications. The optical density of destaining solution after washing crystal violet adsorbed onto biofilm was measured with a multi-well plate spectrophotometer (using a 96 well titer plate). The color intensity of destaining solution after washing has been shown to be proportional to the quantity of biofilm formed. This method makes more practical high-throughput screening of polymer surfaces for their antibiofilm activity.

Metallic silver/ $/ \mathrm{TiO}_{2}$ and silver ion doped $\mathrm{TiO}_{2}$ system in the form of films, deposition and its antibacterial performance in visible/UV light have been reported frequently [23-25]. To the best of our knowledge, there have been limited reports on the synthesis of polymers loaded with silver doped titania, for durable photobactericidal coatings that is compatible with many substrates to fight biofilms. In this work, composite materials suitable for coating was obtained by the addition of $\mathrm{Ag}-\mathrm{TiO}_{2}$ nanoparticles into epoxy resin system, with the aim to achieve "in situ" formation of silver species by photoreduction. The antibiofilm activity of this composite system is exhibited by the actions of photokilling and release of biocide $\left(\mathrm{Ag}^{+} / \mathrm{Ag}^{0}\right)$ upon contact with aqueous environment.

\section{Experimental Section}

\subsection{Preparation of Nanocrystalline $\mathrm{TiO}_{2}$ and $\mathrm{Ag}-\mathrm{TiO}_{2}$}

Ethanol 99.9\%, Titanium(IV) butoxide, silver nitrate and acetic acid were of analytical grade and procured from Sigma Aldrich (Bangalore, India). About $1.5 \mathrm{wt} \% \mathrm{of}_{\mathrm{Ag}^{+}}$ion doped nanocrystalline anatase $\mathrm{TiO}_{2}$ was prepared by homogeneous hydrolysis of titanium butoxide-ethanolic solution using acetic acid-water as acid catalyst. The stoichiometric amount of $\mathrm{AgNO}_{3}$ was dissolved in aqueous acetic acid and then added drop wise into the titania sol with stirring for $30 \mathrm{~min}$ at room temperature, and allowed to stand for two days at room temperature. Undoped $\mathrm{TiO}_{2}$ gel was prepared by the same 
procedure without the addition of $\mathrm{AgNO}_{3}$. All the gels were isochronally annealed initially at $100{ }^{\circ} \mathrm{C}$ for $2 \mathrm{~h}$ then at $500{ }^{\circ} \mathrm{C}$ for $4 \mathrm{~h}$.

\subsection{Nanocomposite Preparation and Coating}

The commercial grade resins, Lapox ${ }^{\circledR}$ L-12 [liquid epoxy resin based on bisphenol-A, (4,4'-Isopropylidenediphenol, oligomeric reaction products with 1-chloro-2,3-epoxypropane)] and reactive diluent, Lapox ${ }^{\circledR}$ XR-19 (Diglycidyl ether of polypropylene glycol) were procured from Atul Ltd., Ahmedabad, India. Diethylenetriamine (DETA) as a curative agent from Sigma-Aldrich was employed. The low molecular weight epoxy Lapox ${ }^{\circledR}$ XR-19, was added as diluents to lower the viscosity of the base resin and improve the initial physical dispersion of $\mathrm{TiO}_{2}$ in the epoxy. The nanocomposites were prepared as follows: (i) the resin mixture was prepared (resin + diluant); (ii) the resin solution was diluted with ethanol to further decrease the viscosity of the resin mixture at 1:5 ratio; (iii) different amount of $\mathrm{TiO}_{2}$ or $\mathrm{Ag}-\mathrm{TiO}_{2}$ was mixed into the diluted resin mixture. Then, the mixtures were sonicated under water bath for $30 \mathrm{~min}$ and degassed under vacuum. The resin-to-curative ratio in the material preparation at $10 \%$ of resin mixture weight was added. The mixtures were spin coated into the $50 \mathrm{~mm} \times 12 \mathrm{~mm}$ (outer dia $\times$ height) size Borosil ${ }^{\circledR}$ S-Line petri plate on flat bottom dish and allowed to dry at room temperature for $24 \mathrm{~h}$. The coatings were postcured at $100{ }^{\circ} \mathrm{C}$ for $2 \mathrm{~h}$. Six different material samples were coated - neat epoxy resin, undoped $\mathrm{TiO}_{2}$ /epoxy composite with $1 \mathrm{wt} \%$ loading and $\mathrm{Ag}-\mathrm{TiO}_{2}$ /epoxy composite with 0.5, 1.0, 1.5 and $2.0 \mathrm{wt} \%$ loading Figure 1. The epoxy/Ag-TiO composite turned pale brown indicating the formation of silver nanoparticles due to photoreduction. The coated substrates were sterilized by autoclaving at $121{ }^{\circ} \mathrm{C}$, for $15 \mathrm{~min}$ before the start of experiments.

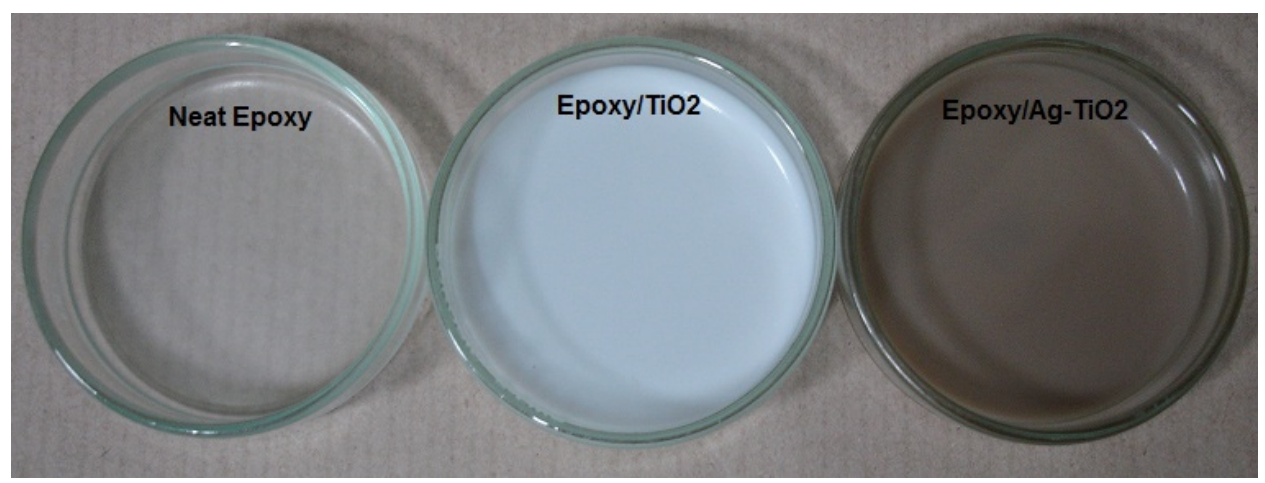

Figure 1. Assay petri dishes spin coated with neat epoxy, epoxy/ $\mathrm{TiO}_{2}$ and epoxy/Ag- $-\mathrm{TiO}_{2}$ composites.

\subsection{Physicochemical Characterization}

Powder X-ray diffraction (PXRD) measurements were recorded by Bruker D8 Advance (Bruker AXS Inc., Madison, WI, USA) X-ray diffractometer with $\mathrm{Cu}$ K $\alpha$ radiation (1.5418 $\AA$ ) at a $40 \mathrm{kV}$ accelerating voltage and $30 \mathrm{~mA}$. Raman measurements were performed with Renishaw Raman Microspectrometer (RM1000 System, Renishaw, Tokyo, Japan) of spectral resolution of $1 \mathrm{~cm}^{-1}$ and spatial resolution of $\sim 2.5 \mathrm{~nm}$ (using 50X Objective and $514.5 \mathrm{~nm}$ laser line). Scanning electron microscopy (SEM) images were captured using a Philips XL30 CP microscope equipped with EDX (energy dispersive X-ray) (Philips, Eindhoven, The Netherlands). The Brunauer-Emmett-Teller (BET) surface area (calculated from nitrogen adsorption data) was measured on a Quantachrome NOVA 1000 system at $-180{ }^{\circ} \mathrm{C}$. 
UV-Vis diffuse reflectance spectra (DRS) were recorded using Analytik Jena Specord S600 spectrometer (Analytik Jena AG, Jena, Germany) (diffuse reflectance accessory with integrating sphere) by using $\mathrm{BaSO}_{4}$ as a reference. All the above charecterizations were performed for the prepared nanocrystalline $\mathrm{TiO}_{2}$ and $\mathrm{Ag}-\mathrm{TiO}_{2}$. The thermal property of composite materials was investigated by differential scanning calorimetry using Mettler-Toledo DSC823e (Mettler-Toledo AG, Schwerzenbach, Switzerland), and scans were performed at $5{ }^{\circ} \mathrm{C} / \mathrm{min}$ for each composite under nitrogen flow and $T_{\mathrm{g}}$ value was extrapolated from the curves of second run.

\subsection{Quantitative Determination of Biofilm}

Bacteria used in this study were biofilm-proficient $S$. aureus ATCC 6538 and E. coli K-12 strains. Biofilm formation was measured under static condition by adopting quantitative crystal violet $(\mathrm{CV})$ binding assay of Kwasny and Opperman with modifications [22]. In the current study, the flat inner surface of glass petri dish coated with prepared composites and resin was overlaid with $4 \mathrm{~mL}$ of sterile nutrient broth (composition is tabled in Supplementary Materials), so that the total area of the coating was covered. Then, $0.1 \mathrm{~mL}$ of logarithmic phase cultures of either E. coli or $S$. aureus grown over night to an optical density of $c a .0 .1$, at $595 \mathrm{~nm}$ in the appropriate growth media, were inoculated into sterile media in coated bottom plates prepared as above. Inoculated bottom plates were incubated in a bacteriological incubator at $37^{\circ} \mathrm{C}$ under UV-A irradiation with intensity of $0.2 \mathrm{~mW} / \mathrm{cm}^{2}$ with $\lambda_{\max }$ around $365 \mathrm{~nm}$ (which is harmless to cause bacterial reduction), for different exposure durations. Later, the broth with planktonic cells was discarded by decantation. The plates were washed twice by gentle swirling with $2 \mathrm{~mL}$ of sterile phosphate-buffered saline to remove any non-adherent cells. Cells which remained adherent (biofilm mass) to the surface of polymer coated bottom plate were fixed by heating in a hot air oven at $60{ }^{\circ} \mathrm{C}$ for $60 \mathrm{~min}$. Later plates were cooled to room temperature and stained with $1 \mathrm{~mL}$ of $0.06 \%(\mathrm{w} / \mathrm{v})$ solution of crystal violet which was allowed to stand at room temperature for $5 \mathrm{~min}$. Then plates were washed several times with phosphate-buffered saline to remove excess $\mathrm{CV}$ staining. Biofilm bound $\mathrm{CV}$ was eluted by vortexing with $1 \mathrm{~mL}$ of $30 \%$ acetic acid (destaining solution) for $10 \mathrm{~min}$. The $0.2 \mathrm{~mL}$ aliquots of the wash solution with eluted crystal violet were transferred to 4 different wells of 96-well microtiter plates for the purpose of measuring the absorbance at $600 \mathrm{~nm}$. Results were expressed as inhibition percentages of biofilm development. The percent inhibition of biofilm growth produced by each nanocomposite surface was calculated with the formula,

$$
\left\{1-\left[\mathrm{CV} \mathrm{OD}_{600} \text { (composite) } / \text { average } \mathrm{CV} \mathrm{OD}_{600}(\text { negative control })\right]\right\} \times 100
$$

where $\mathrm{CV}^{\mathrm{O}} \mathrm{D}_{600}$ is OD of crystal violet destaining solution obtained at $\lambda_{\max } 600 \mathrm{~nm}$. The results are presented as the average of four individual replicates. To check the binding affinity of CV to the prepared composites and neat epoxy, a similar assay with $48 \mathrm{~h}$ of UV exposure was conducted as above with the plain broth which was not inoculated with bacteria. The OD of destaining solution when measured was found to be insignificant to interfere with the experimental results. Then, the resulting silver concentrations in the same plain broth were also quantified by atomic absorption spectroscopy (AAS) analysis, released into the exposed media by the composites of different $\mathrm{Ag}-\mathrm{TiO}_{2}$ loadings. AAS analysis of released silver concentration was carried out with a 7700X instrumentation (Agilent, Santa Clara, CA, USA), using different standard concentrations. 
The reduction in biofilm colonization on composite was also determined in terms of CFU (colony forming unit), by sonicating assayed composite plate with $5 \mathrm{~mL}$ PBS for $5 \mathrm{~min}$ to remove adherent bacteria. The PBS suspension of released cells was then diluted appropriately, and spread on nutrient agar plate. The bacterial CFUs per milliliter of PBS that formed upon the medium was determined after incubation for $48 \mathrm{~h}$ at $37{ }^{\circ} \mathrm{C}$. The experiment was repeated two times under identical conditions along with negative control (neat epoxy). The biofilm log reduction values were determined as difference between $\log _{10} \mathrm{CFU} /$ plate recovered from the treated plates and $\log _{10} \mathrm{CFU} /$ plate recovered from control plate (neat epoxy). Each experiment was conducted with three replications for each composite plates and colonies were enumerated to obtain the log reduction.

\section{Results and Discussion}

\subsection{Characterization of Materials}

Sol-gel derived nanocrystalline $\mathrm{TiO}_{2}$ were subjected to the XRD analysis to determine crystalline phase and crystallite size. Titania exists in three crystalline polymorphs-anatase, rutile and brookite forms. Among these, anatase titania has been shown to exhibit higher antimicrobial activity than the other two and thus pure anatase phase content is a desirable feature [26]. The PXRD of titanias synthesized in this work had the peaks characteristic of anatase phase Figure 2a. (JCPDS No. 21-1272). From the X-ray diffraction patterns, the size of anatase $\mathrm{TiO}_{2}$ materials prepared were in the nanometric scale Table 1. The average crystallite size was determined from the (101) plane in the PXRD pattern using Scherer's formula. The calculated value of undoped $\mathrm{TiO}_{2}$ had bigger crystallite size while Ag-doped $\mathrm{TiO}_{2}$ showed a decrease in the crystallite size. A good correlation between the Raman and PXRD was also observed Figure $2 \mathrm{~b}$. The changes in the crystallite size of $\mathrm{TiO}_{2}$ nanocrystals upon Ag-doping are closely correlated to the broadening and shifts of the Raman bands with decreasing particle size [27]. Similar observations were made for the titania sysnthesised in the present work. During annealing process, silver nitrate thermally decomposes into silver. Bigger ionic radii of $\mathrm{Ag}^{+}(0.75 \AA)$ compared to $\mathrm{Ti}^{4+}(0.605 \AA)$ prevents it from entering the crystal lattice of anatase $\mathrm{TiO}_{2}$ because of a high energy barrier. Thus, it gets distributed uniformly on the surface of $\mathrm{TiO}_{2}$. However, the PXRD pattern of $\mathrm{Ag}-\mathrm{TiO}_{2}$ did not reveal any $\mathrm{Ag}$ or $\mathrm{Ag}$-containing phases. This may be due to the low concentration of $\mathrm{Ag}$ incorporated which is below the detection limit of the PXRD analysis.

Doping with $\mathrm{Ag}^{+}$ion also resulted in increase in the BET surface area of $\mathrm{TiO}_{2}\left(48 \mathrm{~m}^{2} / \mathrm{g}\right)$, while that of undoped $\mathrm{TiO}_{2}$ showed BET surface area of $27 \mathrm{~m}^{2} / \mathrm{g}$. Thus, large surface area to volume ratio of Ag-doped $\mathrm{TiO}_{2}$ was advantageous for the release of $\mathrm{Ag}^{+}$ion. From the energy dispersive X-ray (EDS) analysis at two locations (see Figure 3a), done during the SEM confirms silver is dispersed uniformly in $\mathrm{TiO}_{2}$ host. Figure $3 \mathrm{~b}$ shows the changes in the absorbance of $\mathrm{Ag}$-doped $\mathrm{TiO}_{2}$ in comparison to undoped $\mathrm{TiO}_{2}$ and Degussa P 25 titania. Ag doped $\mathrm{TiO}_{2}$ (calcined in ambient air at $500{ }^{\circ} \mathrm{C}$ ) was found to have higher visible absorbance. In contrast, pure $\mathrm{TiO}_{2}$ prepared under similar experimental conditions, had its absorbance slightly shifted towards the visible region as compared to Degussa P25 titania (Figure 3b). The DRS spectra showed a characteristic absorption band at about $500 \mathrm{~nm}$, due to the surface plasmon resonance of silver [28]. Using the different absorbance onsets, it was found that the $\mathrm{Ag}-\mathrm{TiO}_{2} \mathrm{had}$ a bandgap of $\sim 2.8 \mathrm{eV}$ while both of the undoped titania samples had wider band gaps estimated at 
$\sim 3.1 \mathrm{eV}$ for $\mathrm{TiO}_{2}$ and $\sim 3.2 \mathrm{eV}$ for the Degussa $\mathrm{P} 25 \mathrm{TiO}_{2}$ sample. Similar observations from previous studies can be confirmed [29].

Table 1. Physio-chemical properties of nanofiller, $T_{\mathrm{g}}$, weight of coated composite material and amount of silver ion released.

\begin{tabular}{|c|c|c|c|c|c|}
\hline \multirow[b]{2}{*}{ Composite type } & \multicolumn{2}{|c|}{ Nanocrystalline- $\mathrm{TiO}_{2}$} & \multicolumn{2}{|c|}{ Epoxy- $\mathrm{TiO}_{2}$ composite } & \multirow{2}{*}{$\begin{array}{c}\text { Amount of Ag released } \\
\text { by the composite } \\
(\mu \mathrm{g} / \mathrm{mL})^{*}\end{array}$} \\
\hline & $\begin{array}{l}\text { Crystallite } \\
\text { size (nm) }\end{array}$ & $\begin{array}{c}\text { BET surface } \\
\text { area }\left(\mathrm{m}^{2} / \mathbf{g}\right)\end{array}$ & $\begin{array}{c}\text { Glass transition } \\
\text { temperature } T_{\mathrm{g}}\left({ }^{\circ} \mathrm{C}\right)\end{array}$ & $\begin{array}{c}\text { Weight of the coated } \\
\text { composite (gm) }\end{array}$ & \\
\hline Neat Epoxy & $\mathrm{n} / \mathrm{a}$ & $\mathrm{n} / \mathrm{a}$ & 93 & 1.08 & Nil \\
\hline $1.0 \mathrm{wt} \%$ Epoxy $/ \mathrm{TiO}_{2}$ & 36 & 27 & 90 & 0.99 & Nil \\
\hline $0.5 \mathrm{wt} \%$ Epoxy $/ \mathrm{Ag}-\mathrm{TiO}_{2}$ & 18 & 48 & 94 & 1.09 & 6.6 \\
\hline $1.0 \mathrm{wt} \%$ Epoxy $/ \mathrm{Ag}-\mathrm{TiO}_{2}$ & 18 & 48 & 97 & 0.95 & 10.2 \\
\hline $1.5 \mathrm{wt} \%$ Epoxy $/ \mathrm{Ag}-\mathrm{TiO}_{2}$ & 18 & 48 & 106 & 1.05 & 14.6 \\
\hline $2.0 \mathrm{wt} \%$ Epoxy $/ \mathrm{Ag}-\mathrm{TiO}_{2}$ & 18 & 48 & 97 & 1.10 & 16.8 \\
\hline
\end{tabular}

* Concentration of silver in the exposure media as determined by Atomic Absorption Spectroscopy (AAS), after $48 \mathrm{~h}$.
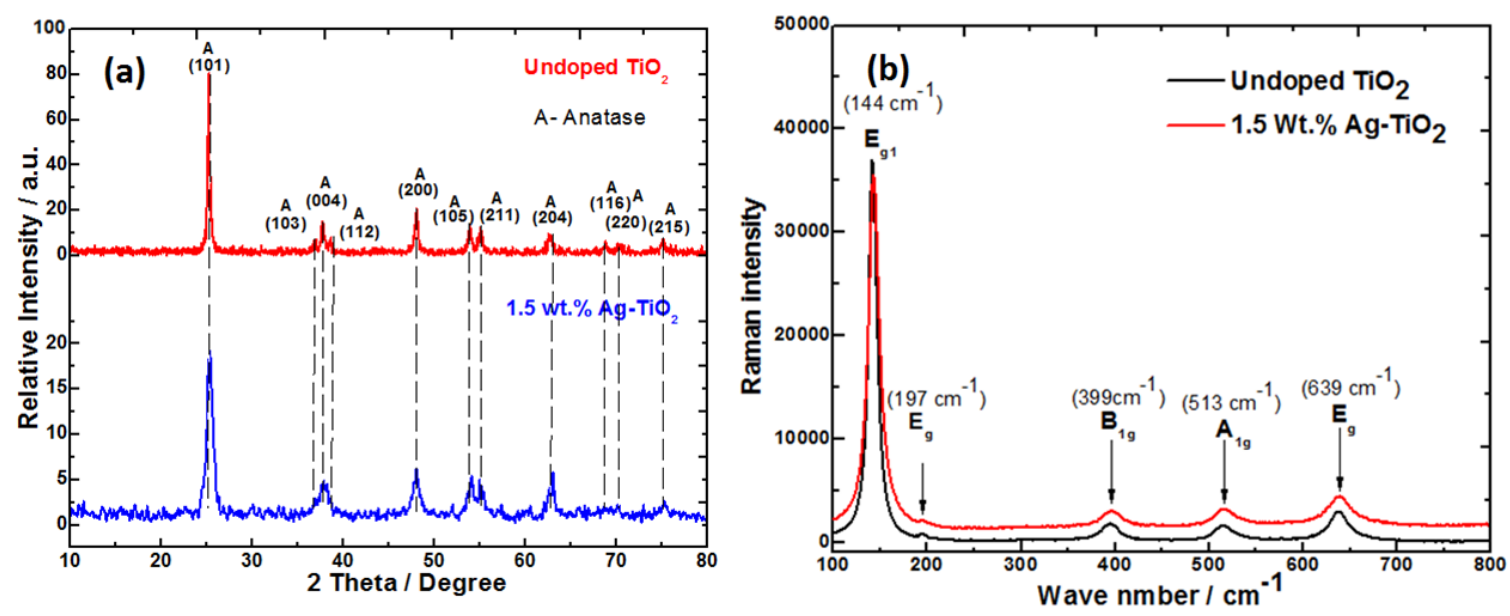

Figure 2. (a) Powder X-ray diffraction (XRD) and (b) Raman spectra of $\mathrm{TiO}_{2}$ and $\mathrm{Ag}-\mathrm{TiO}_{2}$.
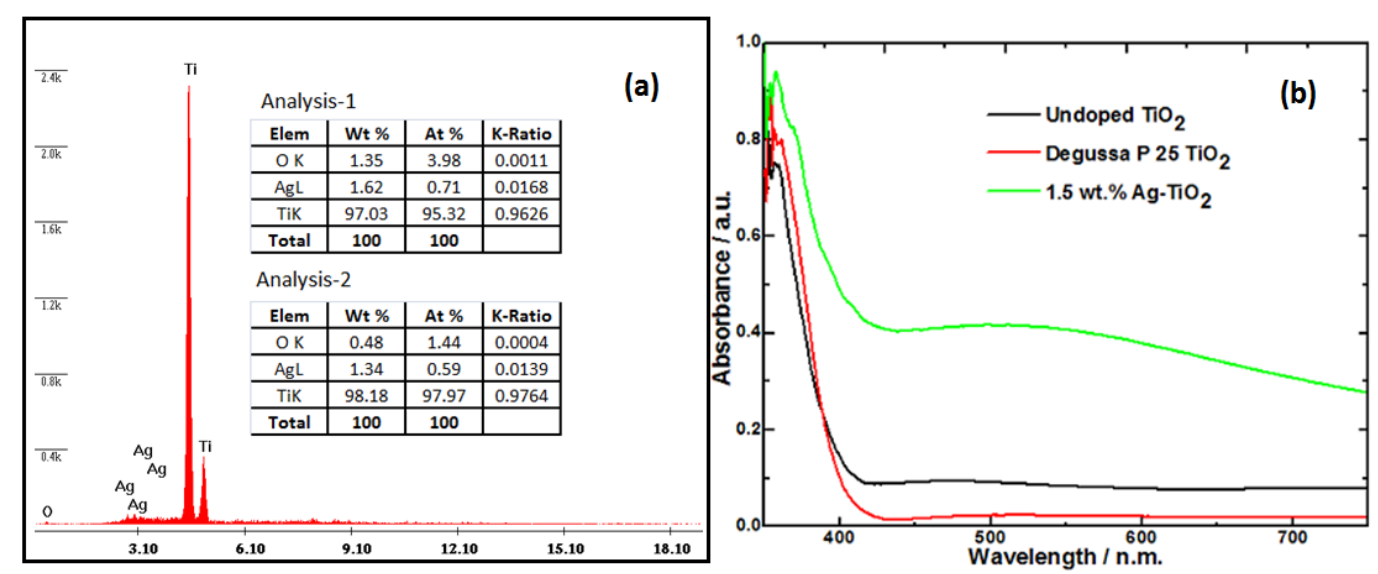

Figure 3. (a) Elemental analysis (EDS) of the silver doped $\mathrm{TiO}_{2}$ showing the presence of $\mathrm{Ti}$ and Ag species; (b) UV-Vis diffuse reflectance spectra (DRS) of Ag-doped $\mathrm{TiO}_{2}, \mathrm{TiO}_{2}$ and Degussa P25 titania. 
The homogeneous distribution of nano-filler in a polymer matrix has major influence on the composite performance. The morphology of synthesized titania nanoparticles and their dispersion in epoxy matrix were examined by SEM analysis Figure 4. The primary particle size of undoped and silver doped titania are different, varying from nanometer to micron size for the same magnification as seen in SEM micrographs Figure 4a,b. The undoped sample exhibited a nanostructure consisting of spherical clusters with a diameter of 50-500 nm, which are extensively agglomerated with an average crystallite size of $36 \mathrm{~nm}$. However, silver doped titania showed bigger aggregates and smaller segregated particles consisting of primary anatase nanocrystals of $18 \mathrm{~nm}$ size (Figure 4b). Dispersion is an important factor in determining a nanocomposite's properties. Composites with the same weight percent ( $1 \mathrm{wt} \%)$ of nanofiller showed different degree of dispersion Figure 4c,d. The unmodified $\mathrm{TiO}_{2}$ although thoroughly distributed in the matrix, yet particles agglomerated densely as shown in Figure $4 \mathrm{c}$ giving scattered hill lock like appearance on the surface of the composite. The size of these agglomerates varied from nanometers to micrometers. However, the $\mathrm{Ag}-\mathrm{TiO}_{2}$ particles Figure 4d, showed a lesser degree of agglomeration; interparticle distance are clearly visible between the $\mathrm{TiO}_{2}$ particles. This indicates that the presence of silver enable good dispersion due to the interaction of oxidized silver ions with surface hydroxyl groups (titanol groups, $\mathrm{Ti}-\mathrm{OH}$ ) of $\mathrm{TiO}_{2}$ and increase its wettability in apolar media like epoxy (hydrophobic polymer matrix). While Figure 4e shows the fractured surface of the composite, dispersion in the bulk is similar to distance between agglomerates as on surface. This suggests that the doped nano-fillers have better dispersion due to surface modifications, which improve the interactions between particles and polymer matrix. Use of reactive diluant also significantly reduced viscosity of epoxy resin during preparation and optimized the dispersion along with sonication.
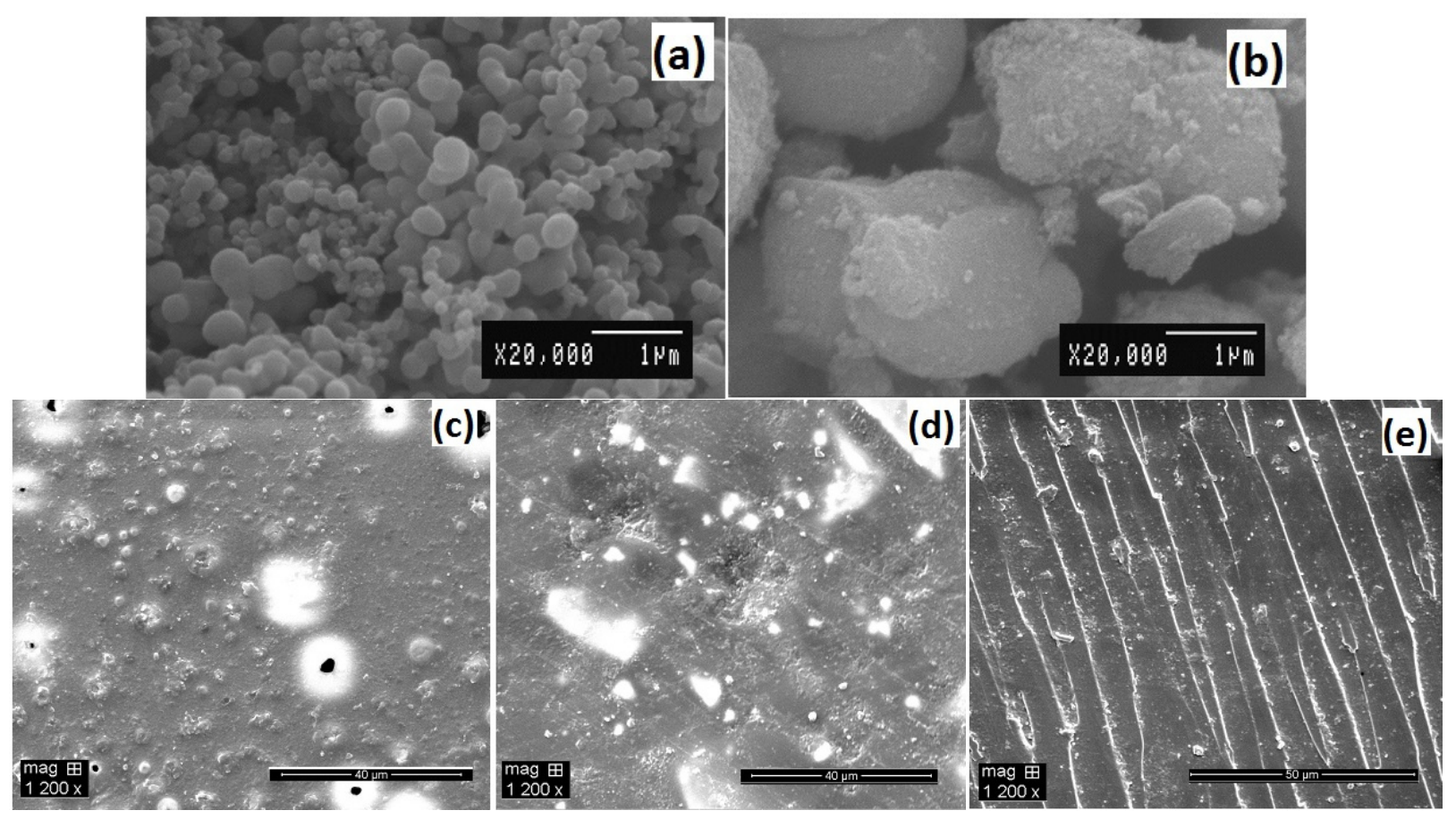

Figure 4. Scanning electron microscopic (SEM) characterization of (a) sol-gel synthesized $\mathrm{TiO}_{2}$; (b) $1.5 \mathrm{wt} \%$ silver doped $\mathrm{TiO}_{2}$; (c) $1 \mathrm{wt} \%$ epoxy $/ \mathrm{TiO}_{2}$ composite; (d) $1 \mathrm{wt} \%$ epoxy $/ \mathrm{Ag}-\mathrm{TiO}_{2}$ composite; (e) Fractured surface of $1 \mathrm{wt} \%$ epoxy/Ag- $\mathrm{TiO}_{2}$ composite. 
The glass transition temperature $\left(T_{\mathrm{g}}\right)$ of the samples were determined from the tangents of DSC spectra as a function of temperature. The DSC curves of the neat epoxy and nanocomposites with $1 \mathrm{wt} \%$ of $\mathrm{TiO}_{2}$ and $\mathrm{Ag}-\mathrm{TiO}_{2}$ nanofiller from the second run are shown in the Figure 5a. For thermosetting resin glass transition temperature $\left(T_{\mathrm{g}}\right)$, values can shift due to reasons like cross-linking density, intermolecular interaction and chain length. The addition of nanometer sized $\mathrm{TiO}_{2}$ particles in epoxy resulted in increase in the $T_{\mathrm{g}}$ from $93{ }^{\circ} \mathrm{C}$ for neat epoxy to $97{ }^{\circ} \mathrm{C}$ at $1 \mathrm{wt} \%$ loading of $\mathrm{Ag}-\mathrm{TiO}_{2}$. Whereas, $T_{\mathrm{g}}$ of composite shifts to lower temperature with undoped $\mathrm{TiO}_{2}$ ( $1 \mathrm{wt} \%$ loading) due to poor dispersion and agglomeration as evident in the SEM micrograph. Nanocomposites with $\mathrm{Ag}^{-\mathrm{TiO}_{2}}$ exhibited maximum $T_{\mathrm{g}}$ value at $1.5 \mathrm{wt} \%$ loading $\left(107^{\circ} \mathrm{C}\right.$ ) (Figure $5 \mathrm{~b}$ ). A further increase in the nano-filler content to $2 \mathrm{wt} \%$ led to the drop in the $T_{\mathrm{g}}$ value, this is due to their easy agglomeration arising from van der Waals attraction between particles.
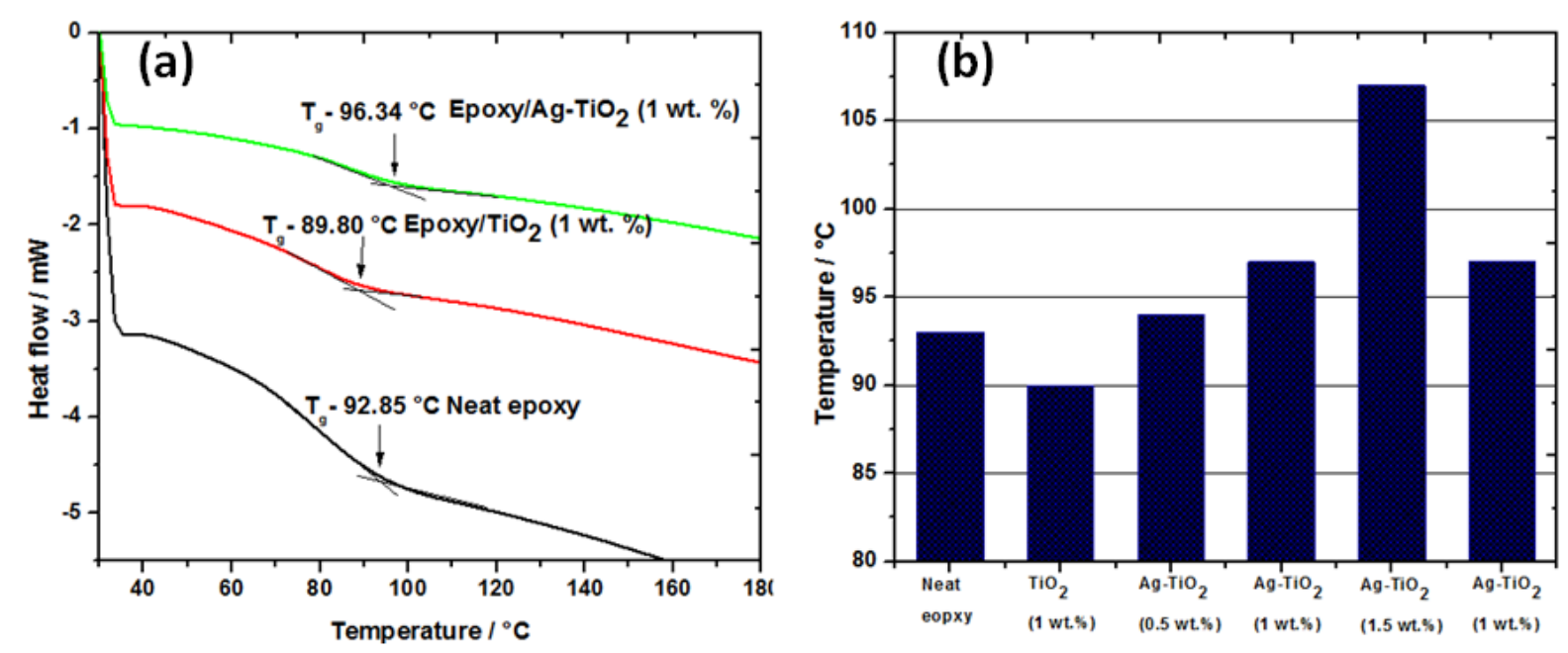

Figure 5. (a) DSC thermograms of neat epoxy and nanocomposites with $1 \mathrm{wt} \%$ of $\mathrm{TiO}_{2}$ and $\mathrm{Ag}_{-} \mathrm{TiO}_{2}$; (b) Variations in $T_{\mathrm{g}}$ values of neat resin and nanocomposites at different $\mathrm{wt} \%$ of $\mathrm{TiO}_{2} / \mathrm{Ag}-\mathrm{TiO}_{2}$ loading.

It can be seen from Figure $5 \mathrm{~b}$ that the $T_{\mathrm{g}}$ value increases steadily then value drops; this corroborates with the trend observed by other investigators $[13,30]$. With our study, the degree of dispersion and nanofiller loading affected the shifts in $T_{\mathrm{g}}$ for epoxy/Ag- $\mathrm{TiO}_{2}$ composites. The size, loading and dispersion state of the nanofillers are the factors that impact the glass-transition temperature. The $T_{\mathrm{g}}$ value increases due to polymer chain-filler (organic-inorganic interfacial contact) that are immobilized by cohesive interactions at the interface of nanofiller in the bulk of the material. On the other hand, higher loading of nanofiller or their agglomeration can result in mobile moieties within the matrix which significantly decrease the glass transition temperature. Very high $T_{\mathrm{g}}$ values are not achievable by room temperature curing agents, and the composites reported here can find their applications at temperature conditions below their $T_{\mathrm{g}}$. These synthesized epoxy composites may be cross linked by means of any conventional hardener at room temperature, without the decomposition of incorporated biocides.

\subsection{Antibiofilm Activity on the $\mathrm{TiO}_{2}$ and $\mathrm{Ag}-\mathrm{TiO}_{2} \mathrm{Nanocomposite}^{\mathrm{Coatings}}$}

Antibacterial epoxy coatings for antibiofilm properties were tested against $S$. aureus and $E$. coli under static conditions in glass petri dish with UV-A irradiation, on the surfaces of $\mathrm{TiO}_{2}$ and $\mathrm{Ag}-\mathrm{TiO}_{2}$ 
composites (both with $1 \mathrm{wt} \%$ loading). Both $S$. aureus and E. coli were able to form biofilm on neat epoxy resin surface (negative control) and composites, i.e., biofilm formation was independent of the underlying composite substrates. In the absence of $\mathrm{TiO}_{2}$, epoxy resin showed higher growth of biofilm than that of epoxy/ $\mathrm{TiO}_{2}$ composite. Anti-boifilm activity appeared to increase significantly for $\mathrm{Ag}-\mathrm{TiO}_{2}$ composite.

The biofilm inhibition by composites does not seem to be restricted to specific strains or growth conditions; E. coli and $S$. aureus varied in their ability to produce biofilm on the surface of the composites as shown in Figure 6. In all assays, the amount of crystal violet eluted from E. coli biofilms was lower than that of $S$. aureus biofilms, because $E$. coli, being a Gram negative organism binds lesser dye than Gram positive organisms like $S$. aureus. The OD 600 of CV eluates from both biofilms was in the range of 0.121 to 2.8 . Among the bacterial pathogens, E. coli was more susceptible for biofilm inhibition than $S$. aureus on these surfaces.

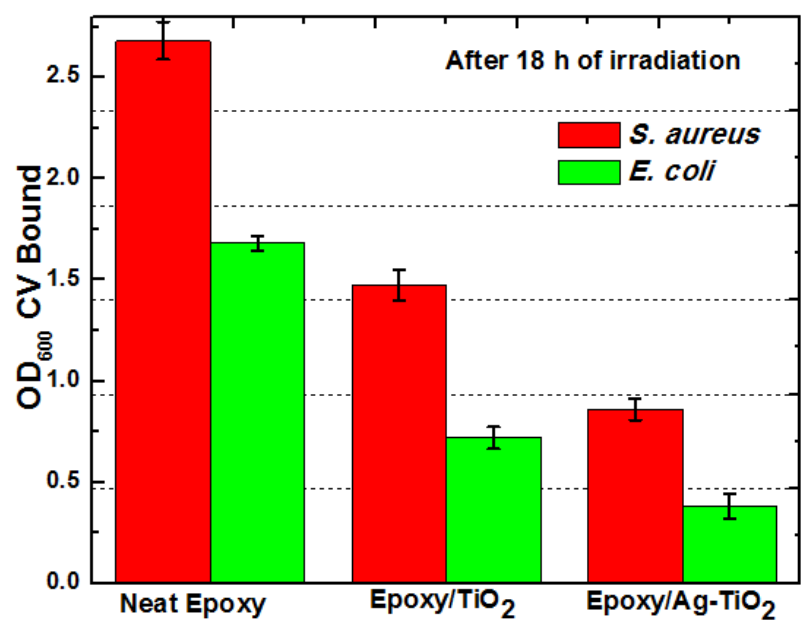

Figure 6. Spectrophotometric analysis $\left(\mathrm{OD}_{600}\right)$ of solubilized crystal violet of $E$. coli and $S$. aureus biofilm at $18 \mathrm{~h}$ irradiation time on the surfaces of $\mathrm{TiO}_{2}$ and $\mathrm{Ag}-\mathrm{TiO}_{2}$ composite with similar loading (1 wt \%).

To confirm the activity of $\mathrm{TiO}_{2} / \mathrm{Ag}-\mathrm{TiO}_{2}$ on the surface of nanocomposite for the photokilling, we conducted the experiments under both dark and irradiated conditions as shown in Figure 7, and we found that higher inhibition of biofilm under irradiated conditions as shown in Figure $7 \mathrm{~b}$. The $\mathrm{Ag}-\mathrm{TiO}_{2}$ composite ( $1 \mathrm{wt} \%$ ) showed $24 \%$ and $\mathrm{TiO}_{2}$ composite $(1 \mathrm{wt} \%$ ) showed $6 \%$ biofilm inhibition of E. coli after $18 \mathrm{~h}$ of incubation in the dark as shown in Figure $7 \mathrm{a}$. For the same conditions with UV irradiation E. coli biofilm showed $56 \%$ inhibition for epoxy $/ \mathrm{TiO}_{2}$ and $77 \%$ inhibition for epoxy $/ \mathrm{Ag}-\mathrm{TiO}_{2}$, while that of $S$. aureus biofilm showed $43 \%$ and $67 \%$ ihibition, for epoxy $/ \mathrm{TiO}_{2}$ and epoxy/Ag- $\mathrm{TiO}_{2}$ composites respectively. It is, therefore, the bactericidal activity of silver on biofilm that is rendered more likely in the absence of photokilling by $\mathrm{Ag}-\mathrm{TiO}_{2}$ with the dark experiment data. However, enhanced antibiofilm response of $\mathrm{Ag}-\mathrm{TiO}_{2}$ composite under $\mathrm{UV}$ irradiation can be attributed to the silver surface plasmon band favoring UV light absorption along with nanometer sized silver particles which exhibited a striking degree of synergy. The antibacterial feature was diminished for epoxy/ $\mathrm{TiO}_{2}$ composite in the dark experiment. However, the bare $\mathrm{TiO}_{2}$ particles which are non-photo-activated on the surface also supported minor antibacterial activity, even in the dark. This is due to direct attack of cells upon contact 
with $\mathrm{TiO}_{2}$ nanoparticles which disrupt the integrity of the bacterial membrane $[31,32]$. This is also in agreement with reported experimental findings by Gogniat et al. [33] who also showed a loss of bacterial culturability after contact with $\mathrm{TiO}_{2}$ nanoparticles even in the dark. These data show that the nature of epoxy resin makes it suitable host for dispersion of photocatalyst like $\mathrm{TiO}_{2}$ for bacteriacidal activity.
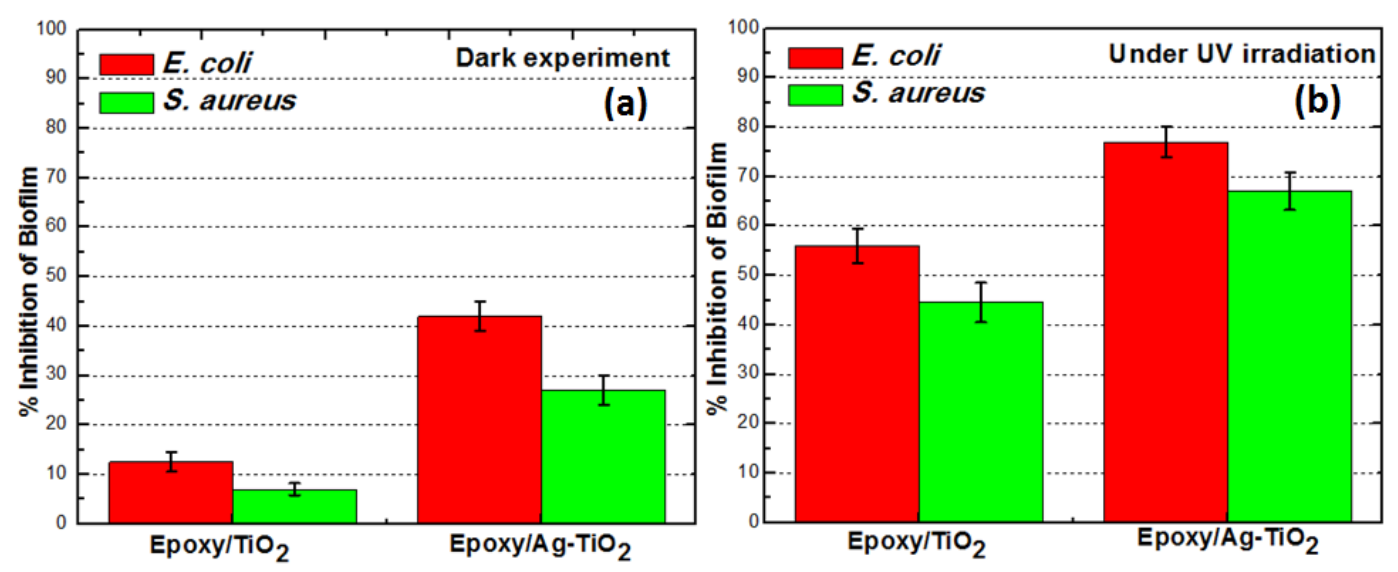

Figure 7. Mean values of quadruplicate experiments showing percent inhibition of $E$. coli and $S$. aureus bio-film formation on epoxy/ $\mathrm{TiO}_{2}$ and epoxy/Ag- $\mathrm{TiO}_{2}$ composite surfaces calculated relative to the neat epoxy (negative control), under (a) dark and (b) UV irradiated conditions.

The release of the antimicrobial species $\left(\mathrm{Ag}^{+}, \mathrm{Ag}^{0}\right.$ and $\left.\mathrm{ROS}\right)$ from a composite occurs due to the interaction of the diffused water molecules with $\mathrm{TiO}_{2}$ and dispersed silver within the matrix during UV exposure; upon submerging it in the culture media [34,35]. Silver ions resident within the metal oxide nanofiller can diffuse to the surface of the epoxy matrix. The leaching of $\mathrm{Ag}^{+}$ions was confirmed by AAS analysis of the bacterial media from blank experiments (without inoculums as explained in the

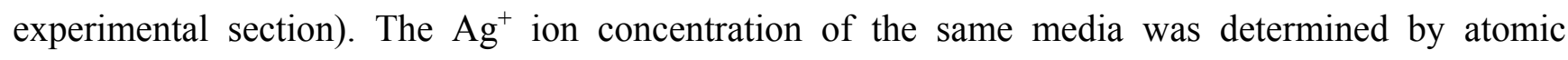
absorption spectrophotometer (AAS), which strongly suggests $\mathrm{Ag}^{+} / \mathrm{Ag}^{0}$ are associated noncovalently with cross-linked polymeric host and has leached to aqueous medium. By AAS analysis, the silver concentration $\left(\mathrm{Ag}^{+} / \mathrm{Ag}^{0}\right)$ in the exposed media for the different epoxy/Ag-TiO 2 composite, showed a nonlinear increase that approached a maximum for the composite with $2.0 \mathrm{wt} \%$ of $\mathrm{Ag}^{-\mathrm{TiO}_{2}}$ loading Table 1.

The valence band "electrons" can be excited to the conduction band $\left(\mathrm{e}_{\mathrm{cb}}^{-}\right)$, leaving positive "holes" in the valence band $\left(\mathrm{h}_{\mathrm{vb}}^{+}\right)$to form an $\mathrm{e}^{-} / \mathrm{h}^{+}$couple that react with aqueous environment and oxygen, to generate reactive oxygen speces (ROS) such as $\mathrm{OH}^{-}, \mathrm{HO}_{2}{ }^{-}$and $\mathrm{O}_{2}{ }^{-}$, which are responsible for the mechanistic photo-biocidal activity [36,37]. The photoexcitation of non-leachably associated $\mathrm{TiO}_{2}$ occurs when it absorbs light equal to or greater than band-gap energy near-ultraviolet light region. While $\mathrm{Ag} \mathrm{NP}$ and $\mathrm{Ag}^{+}$could act as efficient electron scavengers, and significantly enhanced the visible light responsiveness of $\mathrm{TiO}_{2}$ to generate more oxygen free radicals by improving the quantum efficiency of a charge pair generated [35]. At the same time, these oxygen species can reduce $\mathrm{Ag}^{+}$ions to form $\mathrm{Ag}$ nanoparticles. The smaller $\mathrm{Ag}^{+}$ions can easily penetrate the cell wall and thus can hasten antimicrobial activity.

The attack of $\mathrm{Ag}^{+}$on disulfide or sulfhydryl (thiol) groups present in the membrane protein result in formation of stable $\mathrm{S}-\mathrm{Ag}$ bond with $-\mathrm{SH}$ groups thus inhibiting enzyme-catalyzed reactions and the 
electron transport chain that are necessary for biofilm formation [38]. We speculate that the outer membrane of the bacterial cell is attacked by photocatalytic oxidation enabling the antimicrobial metal ions/particles to diffuse to interior of the cell thus becoming much more lethal to the bacterium. Thus, capability of photoactive $\mathrm{TiO}_{2}$ and leachable silver in destabilizing the biofilm matrix is enhanced by synergistic approach.

\subsection{Effect of Exposure Duration on Formation of S. Aureus and E. Coli Biofilms}

Figure 8 shows $\mathrm{OD}_{600}$ values of eluted dye solution by E. coli and $S$. aureus for different duration of exposure ( 6 h, 9 h, 12 h, 15 h, 18 h, 20 h, 22 h and 24 h) of neat epoxy, epoxy/TiO $2(1 \mathrm{wt} \%)$ and epoxy/Ag-TiO 2 (1 wt\%). The biofilm ODs presented are averages of four independent experiments. Time course studies showed bactericidal ability of prepared composite surface up on contact and effectiveness in restraining bacterial biofilm formation. S. aureus biofilm formation response to time increased gradually, but it declined over a longer incubation period. It is plausible that this is due to biosorption of minerals and metals by microbial biofilms from the environment with which they are in contact $[39,40]$. When higher levels of silver is reached or with chronic exposure, it should be possible to limit the ability of the biofilm biosorption capacity, silver would then inhibit biofilm formation during prolonged exposure.
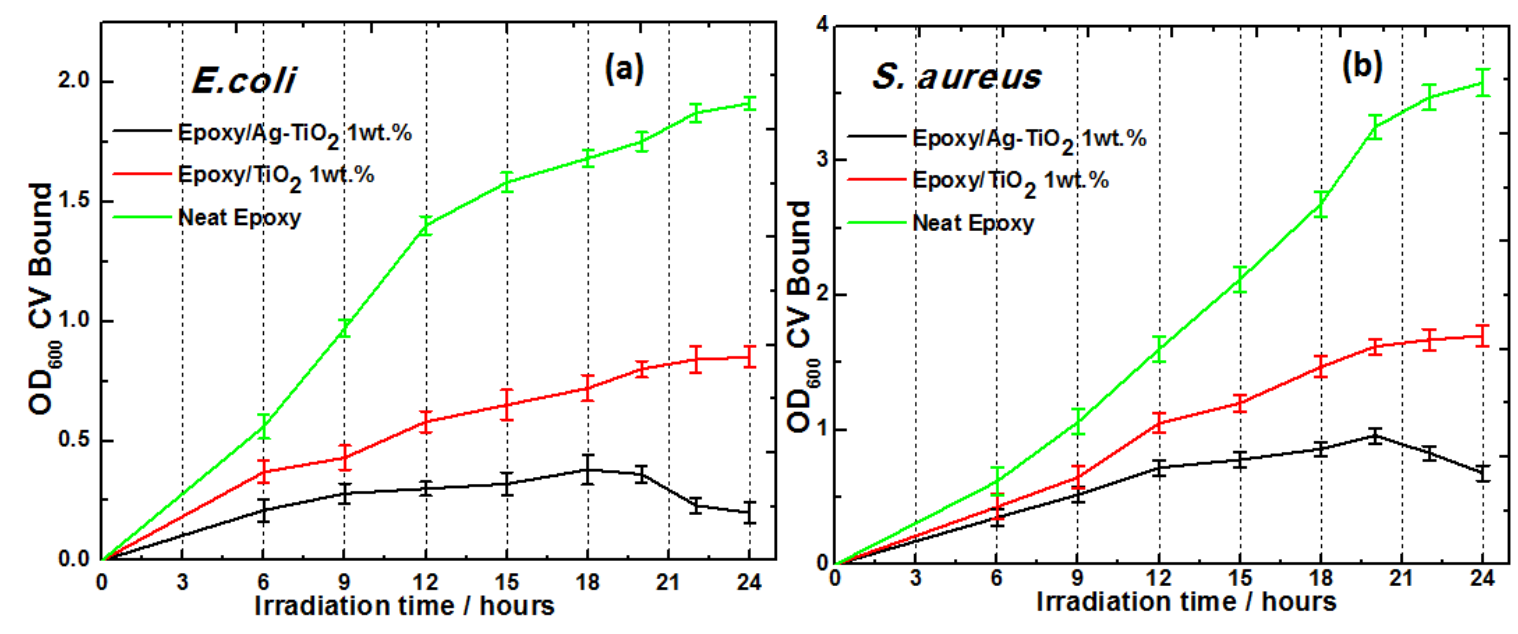

Figure 8. Growth curve for biofilm formation on neat resin, epoxy/ $/ \mathrm{TiO}_{2}$ and epoxy/Ag- $\mathrm{TiO} 2$ composite of (a) E. coli and (b) S. aureus.

\subsection{Effect of $\mathrm{Ag}-\mathrm{TiO}_{2}$ Loading on Biofilm Inhibition}

The results showed that biofilm formation was highly inhibited in a dose dependent manner as shown in Figure 9. Increasing the load of $\mathrm{Ag}-\mathrm{TiO}_{2}$ resulted in shorter inhibition time i.e., antibiofilm activity of composite is directly proportional to $\mathrm{Ag}-\mathrm{TiO}_{2}$ loading. Exposure of the composite with $1.5 \mathrm{wt} \%$ $\mathrm{Ag}-\mathrm{TiO}_{2}$ for $24 \mathrm{~h}$. resulted in a inhibition of $100 \%$ (as per crystal violet binding assay) of both E. coli and $S$. aureus. The higher activity of these composites against E. coli a Gram-negative bacterium is attributed to its thinner peptidoglycan cell wall compared to $S$. aureus a Gram-positive bacterium. Complete inhibition of biofilm was achieved with $24 \mathrm{~h}$ of irradiation time with composite of $\mathrm{Ag}-\mathrm{TiO}_{2}$ with $1.5 \mathrm{wt} \%$ loading, in case of both $E$. coli and $S$. aureus (see Figure 9a,b). The antibacterial activity could also have effect on planktonic bacteria due to silver that has diffused to media from the matrix. 
The bactericidal efficacy of these composite is through the diffusion of photogenerated $\mathrm{ROS}$ and $\mathrm{Ag}^{+}$ particles (acting as a leaching biocide) to the surface from the bulk of the polymer where such species/particles attack proteins and membrane lipids in bacterial cell wall. The driving force for silver particle diffusion is determined by a concentration gradient, which forms between the bulk of the composite material and the surface. The diffusion behavior depends on several factors including the structure of the material, environmental osmolarity and temperature.

We have quantified the silver release characteristics at $37{ }^{\circ} \mathrm{C}$ for the composites loaded with the $0.5 \mathrm{wt} \%$ to $2.0 \mathrm{wt} \% \mathrm{Ag}^{-\mathrm{TiO}_{2}}$ filler Table 1 . And observed that non linear increase in the release of silver on increase of $\mathrm{Ag}-\mathrm{TiO}_{2}$ loading. The total released silver from the coatings was 6.6 to $16.8 \mu \mathrm{g} / \mathrm{mL}$ ( $16.8 \mathrm{ppm}$ ) after $48 \mathrm{~h}$ by epoxy $/ \mathrm{Ag}-\mathrm{TiO}_{2}$ composites in the culture media without inoculum. From this observation it can be concluded that all the $\mathrm{Ag}-\mathrm{TiO}_{2}$ containing composites can have antibacterial activity even in the dark due to release of silver. However, presence of UV light will hasten the bactericidal activity of the composite due to photogeneration of ROS. Similar observations were made by Akhavan and Ghaderi [41] who investigated bactericidal activity of the anatase- $\mathrm{TiO}_{2}$, the $\mathrm{Ag}$ thin film and the $\mathrm{Ag}-\mathrm{TiO}_{2} /$ anatase- $\mathrm{TiO}_{2}$ nanocomposite thin film against $E$. coli at dark and under UV exposure. In addition, they found superior antibacterial activity of $\mathrm{Ag}-\mathrm{TiO}_{2} /$ anatase- $\mathrm{TiO}_{2}$ nanocomposite thin film under the UV irradiation due its photocatalytic capability when compared to non-photocatalytic bare $\mathrm{Ag}$ and $\mathrm{TiO}_{2}$ films and the silver ions released by $\mathrm{Ag}-\mathrm{TiO} /$ anatase- $-\mathrm{TiO}_{2}$ nanocomposite thin film became saturated after 20 days at $\sim 2 \mathrm{nM} / \mathrm{mL}$. It is also possible to regulate the release of silver to the desired concentration by varying the nano-filler load incorporated into polymer composites and by tuning $\mathrm{Ag}-\mathrm{TiO}_{2}$ structure/composition during the sol-gel incorporation process. Antibiofilm activity of these composite remained unchanged at least for 5-6 cycles when we challenged during experiment through replications, this is due to continuous and uniform diffusion of the antimicrobial agents (ROS and silver species).
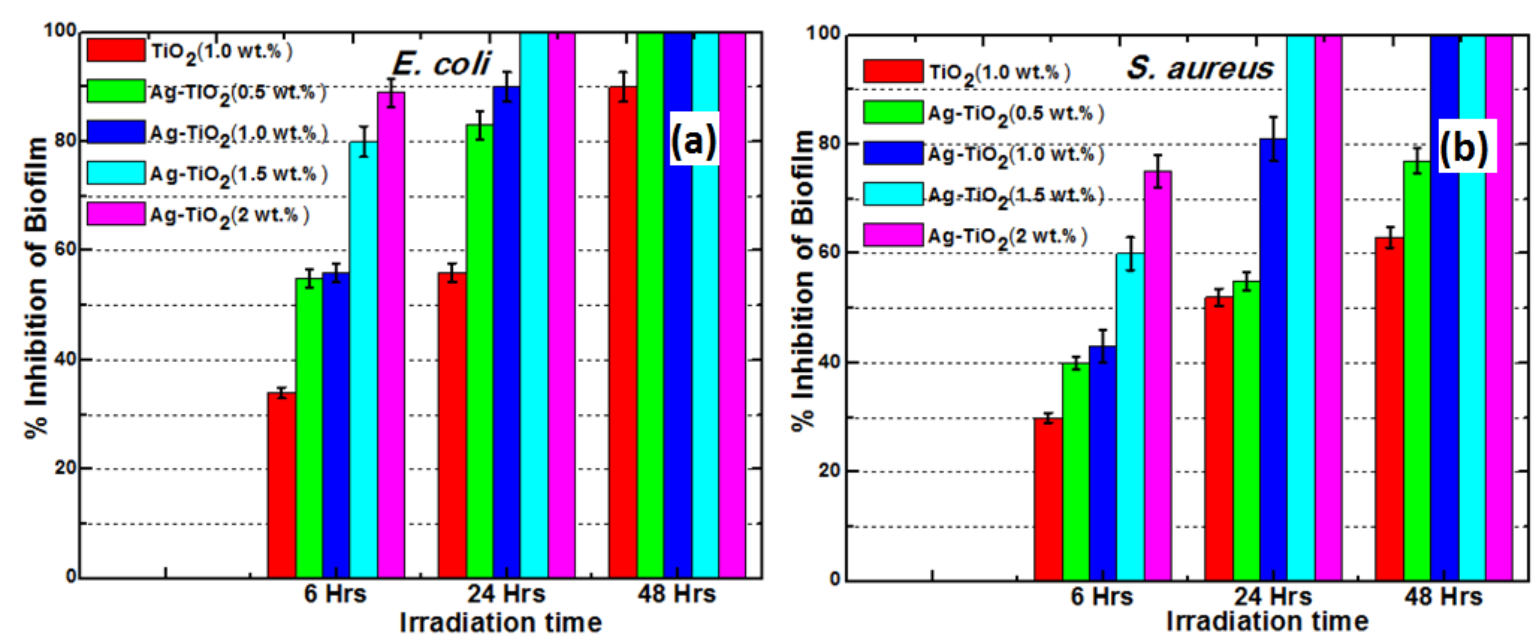

Figure 9. Biofilm inhibitory effect of $\mathrm{Ag}-\mathrm{TiO}_{2}$ loading (dose response) after 6, 24 and $48 \mathrm{~h}$ of irradiation on (a) E. coli and (b) S. aureus. 


\subsection{Quantitative Comparisions}

There is no general consensus evolved for the comparison of efficiency of antibacterial activity of polymers surfaces between the research groups. However, most studies on antibacterial activity are interpreted by the number of surviving colony forming unit $\mathrm{CFU} / \mathrm{mL}^{-1}$ or per unit area. Kubacka et al. [42], studied the antibacterial effect of isotactic polypropylene (iPP) polymeric matrix incorporated with anatase- $\mathrm{TiO}_{2}$ against Pseudomonas aeruginosa (Gram negative) and Enterococcus faecalis (Gram positive). They reported a maximum reduction by ca. 8-9 log in $30 \mathrm{~min}$ in case of P. aeruginosa. Francolini et al. [19] evaluated the effect of (+)-usnic acid incorporated into modified polyurethane surfaces on the biofilm forming ability of $S$. aureus. After three days postinoculation, they found culturable biofilm cell concentration of $S$. aureus on the untreated polymer was $7.3 \log _{10} \mathrm{CFU} / \mathrm{cm}^{2}$ compared to $0.9 \log _{10} \mathrm{CFU} / \mathrm{cm}^{2}$ on the (+)-usnic acid-containing polymer. Cen et al. [20] introduced pyridinium groups at $15 \mathrm{nmol} / \mathrm{cm}^{2}$ on the surface of poly(ethylene terephthalate) (PET) film and demonstrated its bactericidal effect against Escherichia coli. Jansen et al. introduced silver ions by plasma-induced grafting onto polyurethane films which was found to reduce adherent viable bacteria from initial $10^{4}$ cells $/ \mathrm{cm}^{2}$ to zero within $48 \mathrm{~h}$ [43]. Jiang et al. [44] coated silver on silicon rubber substrates and showed decline in number of L. monocytogenes cells post $6 \mathrm{~h}$. After $12 \mathrm{~h}$, there was a reduction of over $2-\log _{10} \mathrm{CFU} / \mathrm{chip}$, and no viable bacteria were detected on both types of silver-coated SR after 18 and $24 \mathrm{~h}$. Sambhy et al. [21] demonstrated antibacterial activity of composites consisting of poly(4-vinyl-N-hexylpyridinium bromide) (NPVP) embedded with silver bromide nanoparticles. They observed no biofilm formation on 1:1 $\mathrm{AgBr} / 21 \%$ NPVP-coated surfaces after $72 \mathrm{~h}$ when incubated for 24-72 h with $P$. aeruginosa suspension $\left(10^{7} \mathrm{CFU} / \mathrm{mL}\right)$ in LB broth. Pant et al. [45] have demonstrated the ability to eliminate up to $99.9 \%$ of pathogenic bacteria on the surface of siloxane epoxy system containing quaternary ammonium moieties. In another work involving epoxy system, Perk et al. [46] observed fungicide, carbendazim supported on poly (ethylene-co-vinyl alcohol) and epoxy resin coating showed the antifungal activity contingent upon release from their polymer supports.

Coatings and thin films based on titania photoctalysts $\left(\mathrm{Ag}^{+}\right.$-doped $\left.\mathrm{TiO}_{2} / \mathrm{Ag}-\mathrm{TiO}_{2} / \mathrm{TiO}_{2}\right)$ that kills microbes under UV and visible light illumination, also have been actively investigated in recent years. Studies by Necula et al. [47], with $\mathrm{TiO}_{2}-\mathrm{Ag}$ composite coating prepared by plasma electrolytic oxidation on implantable titanium substrate, showed the ability to completely kill methicillin-resistant $S$. aureus (MRSA) within $24 \mathrm{~h}$. In yet another investigation by Necula et al. [25], they examined the ion release and antibacterial activity of porous $\mathrm{TiO}_{2}-\mathrm{Ag}$ coating on biomedical alloy disk. Each evaluated samples could release 20.82 and $127.75 \mu \mathrm{g}$ of $\mathrm{Ag}^{+}$per disk and showed markedly enhanced killing of the MRSA inoculums with $98 \%$ and $>99.75 \%$ respectively within $24 \mathrm{~h}$ of incubation, while their silver free counterpart sample allowed the bacteria to grow up to 1000-fold. The non-cumulative release of silver ions of $0.4 \mathrm{ppm}, 0.26 \mathrm{ppm}$ and $0.005 \mathrm{ppm}$ for $1 \mathrm{~h}, 24 \mathrm{~h}$ and 7 days respectively after immersion in water, from nanometer scale $\mathrm{Ag}-\mathrm{TiO}_{2}$ composite film was demonstrated by $\mathrm{Yu}$ et al. [34] and they also reported that $0.4 \mathrm{ppm}$ released silver from $\mathrm{Ag}-\mathrm{TiO}_{2}$ composite film is sufficient to cause almost $100 \%$ killing of E. coli when exposed to UV for $1 \mathrm{~h}$. Studies by Jamuna-Thevi et al. [48], reported nanostuctured $\mathrm{Ag}^{+}$ doped $\mathrm{TiO}_{2}$ coatings deposited by RF magnetron on stainless steel, with overall $\mathrm{Ag}^{+}$ion release

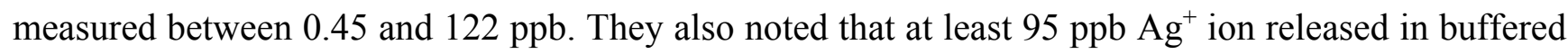
saline was sufficient for $99.9 \%$ of reduction against $S$. aureus after $24 \mathrm{~h}$ of incubation. Biological activity 
of silver-incorporated bioactive glass studies conducted by Balamurugan et al. [49] assessed in vitro antibacterial bioactive glass system elicited a rapid bactericidal action. Antimicrobial efficacy of these silver-incorporated bioglass suspension at $1 \mathrm{mg} / \mathrm{mL}$ for $E$. coli was estimated to be $>99 \%$ killing, and the amount of $\mathrm{Ag}^{+}$released from silver-incorporated glass was up to $0.04 \mathrm{mM}$ after $24 \mathrm{~h}$. In yet another study involving silver ions release by Liu et al. [35], the amount of silver released form the mesoporous $\mathrm{TiO}_{2}$ and $\mathrm{Ag} / \mathrm{TiO}_{2}$ composites was measured to be $1.6 \times 10^{-8}$ mol after 20 days. The photo-bactericidal activity on composite films was extremely high and displayed bactericidal activity even in the dark; they further reported that the survival rate was only $9.2 \%$ in the dark, and the E. coli cells were totally killed in UV light. Sun et al. [50] reported killing of bacteria on $\mathrm{Ag}^{-\mathrm{TiO}_{2}}$ thin film, even in the absence of UV irradiation against $S$. aureus and E. coli with significant antibacterial rate about $91 \%$ and $99 \%$ after $24 \mathrm{~h}$ respectively due to release of silver, and the concentration of silver ions released from the $\mathrm{Ag}-\mathrm{TiO}_{2}$ film was $0.118 \mu \mathrm{g} / \mathrm{mL}$ during $192 \mathrm{~h}$. Akhavan [51], reported that a concentration of 2.8 to $2.5 \mathrm{nM} / \mathrm{mL}$ completely killed $10^{7} \mathrm{CFU} / \mathrm{mL}$ E. coli with visible light response photocatalytic $\mathrm{Ag}-\mathrm{TiO}_{2} / \mathrm{Ag} / \mathrm{a}-\mathrm{TiO}_{2}$ material in $110 \mathrm{~min}$. However, in most of the cases reports are based on planktonic studies and the release of silver is dependent upon the method employed for coating, thickness, conditions for gradient formation and silver source used. Nevertheless, release of silver ions frombare $\mathrm{Ag} / \mathrm{TiO} 2$ composite layers reported above, obtained by methods viz., impregnation, deposition and nano-coatings gradually diminish over the time.

Bacterial biofilms are often more difficult to eradicate unlike planktonic cells. Until now, there have been very few reports that shown to resist biofilm formation on titania based polymer-nanocomposites. In one such study, Kubacka et al. [52] have demonstrated photocatalysis using ethylene-vinyl alcohol copolymer $(\mathrm{EVOH})$ embedded with $\mathrm{Ag}-\mathrm{TiO}_{2}$ nanoparticles ( $c a .10^{-2} \mathrm{wt} \%$ ) that showed outstanding resistance to biofilm formation by bacteria and yeast, upon ultraviolet (UV) light activation. In the present study, although the release kinetics of silver was not established but comparing to above studies which established the antimicribial threshold concentration of silver and efficacy of killing with different bare $\mathrm{Ag}-\mathrm{TiO}_{2}\left(\mathrm{Ag} / \mathrm{Ag}-\mathrm{TiO}_{2}\right.$ nanofilms), the polymer composite system reported here which released 6.4 to $16.8 \mu \mathrm{g} / \mathrm{mL}$ of silver seems adequate [53], when the overall biocidal ability (to prevent bacterial attachment) of the composite during $48 \mathrm{~h}$ period in combination with radical-mediated photocatalytic action. Practically, the added strengths of the polymer-based $\mathrm{Ag}-\mathrm{TiO}_{2}$ nanocomposite coatings as compared to bare $\mathrm{TiO}_{2} / \mathrm{Ag}-\mathrm{TiO}_{2}$ coatings are its wear stability, flexibility, permeability and optical properties.

But the main objective of the disinfection technology in ensuring microbiological safety is to; set a standard for achieving a required logarithm of reduction of the microbial consortia. The microbial cells, which are not inactivated by the antimicrobial coatings adhering onto the testing surface over the different irradiation time, were able to grow on the agar plates. Quantifying their reduction in number (for quantitative assessment) of surviving CFU on a bactericidal surface compared with a non-bactericidal (neat epoxy) surface revealed reduction of microbial cells. In the present study, epoxy/Ag- $\mathrm{TiO}_{2}$ with $1.0 \mathrm{wt} \%$ loading was found to cause a reduction of CFU on agar plates by approximately 6-log in case of $E$. coli and the same effected $c a$. 4-log reduction in case of $S$. aureus after $48 \mathrm{~h}$ of incubation, while epoxy $/ \mathrm{TiO}_{2}$ with $1.0 \mathrm{wt} \%$ loading exhibited lesser inhibition of biofilm formation, see Table 2.

There was an initial slower decrease in bacterial load by all the composites, i.e., below 1-log reduction observed up to $18 \mathrm{~h}$ exposure followed by a rapid microbial decrease up to 6-log in $48 \mathrm{~h}$ for both 
$1.0 \mathrm{wt} \%$ of $\mathrm{TiO}_{2}$ and $\mathrm{Ag}-\mathrm{TiO}_{2}$ loaded epoxy composites. Incomplete inhibition of biofilm formation was observed with lesser $\mathrm{Ag}-\mathrm{TiO}_{2}$ loading, but complete inhibition of both E. coli and $S$. aureus was possible for composites with above $1.5 \mathrm{wt} \%$ of $\mathrm{Ag}-\mathrm{TiO}_{2}$ after $24 \mathrm{~h}$ with UV irradiation. Strikingly, for the composite coating with $2.0 \mathrm{wt} \%$ epoxy/Ag- $\mathrm{TiO}_{2}$ showed highest antibiofilm effectiveness with 1-log reduction in $18 \mathrm{~h}$, i.e., the shortest period with maximum inhibition. In addition, after $48 \mathrm{~h}$ of irradiation against both $S$. aureus and $E$. coli with very few surviving CFUs and complete inhibition (biofilm formation) and 7-log reduction was observed, relative to that in control plates as shown in Table 2. However, the present study results take into consideration only biofilm phase inhibition, and the obtained concentrations of range $6.4-16.8 \mu \mathrm{g} / \mathrm{mL}$ (ppm) $\mathrm{Ag}^{+}$is very high (many times above minimum biocidal concentration levels) to radically prevent microbial cell viability. The polymer-based nanocomposite reported here obtained by dispersion of the $\mathrm{Ag}-\mathrm{TiO}_{2}$ nanoparticles into epoxy manifest a real potential as photobiocidal coatings in a wide variety of settings that prevents biofilm formation by a wide range of Gram-positive and Gram-negative bacteria.

Table 2. Different nanocomposite materials and their antibiofilm efficacy for 18 and $48 \mathrm{~h}$ irradiation time.

\begin{tabular}{|c|c|c|c|c|}
\hline \multirow{2}{*}{ Composite type } & \multicolumn{2}{|c|}{ E. $\operatorname{coli}\left(\mathrm{G}^{-\mathrm{ve}}\right)$} & \multicolumn{2}{|c|}{ S. aureus $\left(\mathrm{G}^{+\mathrm{ve}}\right)$} \\
\hline & \% Inhibition a & $\log _{10}$ Reduction $^{b}$ & \% Inhibition a & $\log _{10}$ Reduction ${ }^{b}$ \\
\hline \multicolumn{5}{|c|}{$\%$ Biofilm inhibition and Log CFU reduction after $18 \mathrm{~h}$} \\
\hline $1 \mathrm{wt} \%$ Epoxy $/ \mathrm{TiO}_{2}$ & $57.2( \pm 1.5)$ & $<1.0( \pm 0.03)$ & $46.0( \pm 1.4)$ & $<1.0( \pm 0.02)$ \\
\hline $1 \mathrm{wt} \%$ Epoxy/AgTiO 2 & $77.0( \pm 1.4)$ & $<1.0( \pm 0.02)$ & $68.5( \pm 2.0)$ & $<1.0( \pm 0.02)$ \\
\hline $2 w t \%$ Epoxy $/ \mathrm{AgTiO}_{2}$ & $90.0( \pm 1.3)$ & $1.0( \pm 0.2)$ & $90.0( \pm 1.4)$ & $1.0( \pm 0.03)$ \\
\hline \multicolumn{5}{|c|}{$\%$ Biofilm inhibition and Log CFU reduction after $48 \mathrm{~h}$} \\
\hline $1 \mathrm{wt} \%$ Epoxy $/ \mathrm{TiO}_{2}$ & $90.0( \pm 1.0)$ & $1.0( \pm 0.2)$ & $63( \pm 0.9)$ & $1.0( \pm 0.2)$ \\
\hline $1 w t \%$ Epoxy/AgTiO 2 & 100 & $6.0( \pm 0.18)$ & $99.9( \pm 0.1)$ & $4.0( \pm 0.11)$ \\
\hline $2 \mathrm{wt} \%$ Epoxy/AgTiO 2 & 100 & $7.0( \pm 0.19)$ & 100 & $7.0( \pm 0.2)$ \\
\hline
\end{tabular}

${ }^{a}$ Percent reduction in biofilm formation as determined by Crystal Violet assay; ${ }^{b}$ Mean value \pm SD for the group $\log 10$ reduction in CFU/plate.

\section{Conclusions}

The investigation relates the preparation of antibiofilm composite coatings containing both photocatalytic non-leaching Ag-doped $\mathrm{TiO}_{2}$ and leaching silver biocide for production of potent oxidants (ROS) and silver species at the surface. The antimicrobial activity of these composite surfaces was quantified based on the inhibition of biofilm formation using crystal violet assay, which can be adopted more conveniently in high-throughput experiments. These antimicrobial materials are capable of killing microorganisms upon contact by inhibiting the biofilm formation in the aqueous environments. Both epoxy $/ \mathrm{TiO}_{2}$ and epoxy/Ag- $\mathrm{TiO}_{2}$ nanocomposites exposed to UV irradiation exhibited antibiofilm activity against S. aureus (Gram-positive) and E. coli (Gram-negative). Although the optimal antimicrobial conditions remain to be fully established, the results highlight a better antibiofilm activity of Epoxy/Ag- $\mathrm{TiO}_{2}$ compared to Epoxy/TiO . The role of different silver species could be that $\mathrm{Ag}^{+}$as an active species found to enhance the catalytic activity, in contrast, $\mathrm{Ag}^{0}$ species showing strong antibacterial activity. This material may find potential applications in designing self-disinfecting surfaces, especially for hospitals and food industries where hygiene is a high priority. 


\section{Acknowledgements}

The authors gratefully acknowledge the support of Rastriya Shikshana Samithi Trust, Bangalore. The authors would also like to acknowledge Department of Materials Engineering, IISc, Bangalore, India, for the help in carrying out the XRD, Raman and SEM analysis. In addition, we acknowledge Aravind K. of Intelli Biotechnologies, Bangalore for helping in microbiological assays.

\section{Author Contributions}

S.S.M. prepared and charecterised the materials, performed the experiments, analyzed the data and designed the structure of manuscript. N.K. gave technical advice and reviewed the manuscript.

\section{Conflicts of Interest}

The authors declare no conflict of interest.

\section{References}

1. Del Pozo, J.L.; Patel, R. The challenge of treating biofilm-associated bacterial infections. Clin. Pharmacol. Ther. 2007, 82, 204-209.

2. Stewart, P.S.; Costerton, J.W. Antibiotic resistance of bacteria in biofilms. Lancet 2001, 358, 135-138.

3. Gupta, S.M.; Tripathi, M. A review of $\mathrm{TiO}_{2}$ nanoparticles. Chin. Sci. Bull. 2011, 56, 1639-1657.

4. Daghrir, R.; Drogui, P.; Robert, D. Modified $\mathrm{TiO}_{2}$ for environmental photocatalytic applications: A review. Ind. Eng. Chem. Res. 2013, 52, 3581-3599.

5. Keleher, J.; Bashant, J.; Heldt, N.; Johnson, L.; Li, Y. Photocatalytic preparation of silver-coated $\mathrm{TiO}_{2}$ particles for antibacterial applications. World J. Microbiol. Biotechnol. 2002, 18, 133-139.

6. Nakano, R.; Hara, M.; Ishiguro, H.; Yao, Y.; Ochiai, T.; Nakata, K.; Murakami, T.; Kajioka, J.; Sunada, K.; Hashimoto, K.; et al. Broad spectrum microbicidal activity of photocatalysis by $\mathrm{TiO}_{2}$. Catalysts 2013, 3, 310-323.

7. McMurray, T.A.; Byrne, J.A.; Dunlop, P.S.M.; Winkelman, J.G.M.; Eggins, B.R.; McAdams, E.T. Intrinsic kinetics of photocatalytic oxidation of formic and oxalic acid on immobilised $\mathrm{TiO}_{2}$ films. Appl. Catal. A General. 2004, 262, 105-110.

8. Chen, D.; Li, F.; Ray, A.K. External and internal mass transfer effect on photocatalytic degradation. Catal. Today 2001, 66, 475-485.

9. Guo, Z.; Pereira, T.; Choi, O.; Wang, Y.; Hahn, H.T. Surface functionalized alumina nanoparticle filled polymeric nanocomposites with enhanced mechanical properties. J. Mater. Chem. 2006, 16, 2800-2808.

10. McIntosh, R.H. Self-sanitizing epoxy resins and preparation thereof. US Patent 4,647,601A, 1987.

11. Sunada, K.; Watanabe, T.; Hashimoto, K. Bactericidal activity of copper-deposited $\mathrm{TiO}_{2}$ thin film under weak UV light illumination. Environ. Sci. Technol. 2003, 37, 4785-4789.

12. Calza, L.R.; Sangermano, M. Investigations of photocatalytic acitivities of different photosensitive semiconductors dispersed into epoxy matrix. Appl. Catal. B Environ. 2011, 106, 657-663. 
13. Chatterjee, A.; Islam, M.S. Fabrication and characterization of $\mathrm{TiO}_{2}$-epoxy nanocomposite. Mater. Sci. Eng. B. 2008, 487, 574-585.

14. Preuss, H.P. Pigments in Paint; Noyes Data Corp.: Park Ridge, NJ, USA, 1974.

15. Schmidt, H. Sol-gel derived nanoparticles as inorganic phases polymer-type matrices. Macromol. Symp. 2000, 159, 43-55.

16. Bittmann, B.; Haupert, F.; Schlarb, A.K. Preparation of $\mathrm{TiO}_{2}$ epoxy nanocomposites by ultrasonic dispersion and resulting properties. J. Appl. Polym. Sci. 2012, 124, 1906-1911.

17. Kugel, A.; Stafslie, S.; Chisholm, B.J. Antimicrobial coatings produced by "tethering" biocides to the coating matrix: A comprehensive review. Prog. Org. Coat. 2011, 72, 222-252.

18. Muñoz-Bonilla, A.; Cerrada, M.; Fernández-García, M.; Kubacka, A.; Ferrer, M.; Fernández-García, M. Biodegradable polycaprolactone-titania nanocomposites: Preparation, characterization and antimicrobial properties. Int. J. Mol. Sci. 2013, 14, 9249-9266.

19. Francolini, I.; Norris, P.; Piozzi, A.; Donelli, G.; Stoodley, P. Usnic acid, a natural antimicrobial agent able to inhibit bacterial biofilm formation on polymer surfaces. Antimicrob. Agents Chemother. 2004, 48, 4360-4365.

20. Cen, L.; Neoh, K.G.; Kang, E.T. Surface functionalization technique for conferring antibacterial properties to polymeric and cellulosic surfaces. Langmuir. 2003, 19, 10295-10303.

21. Sambhy, V.; MacBride, M.M.; Peterson, B.R.; Sen, A. Silver bromide nanoparticle/polymer composites: Dual action tunable antimicrobial materials. J. Am. Chem. Soc. 2006, 128, 9798-9808.

22. Kwasny, S.M.; Opperman, T.J. Static biofilm cultures of Gram-positive pathogens grown in a microtiter format used for anti-biofilm drug discovery. Curr. Protoc. Pharmacol. 2010, 50, doi:10.1002/0471141755.ph13a08s50.

23. Zhang, Q.; Ye, J.; Tian, P.; Lu, X.; Lin, Y.; Zhao, Q.; Ning, G. Ag/TiO 2 and Ag/ $\mathrm{SiO}_{2}$ composite spheres: Synthesis, characterization and antibacterial properties. RSC Adv. 2013, 3, 9739-9744.

24. Sornsanit, K.; Horprathum, M.; Chananonnawathorn, C.; Eiamchai, P.; Limwichean, S.; Aiempanakit, K.; Kaewkhao, J. Fabrication and characterization of antibacterial Ag- $\mathrm{TiO}_{2}$ thin films prepared by DC magnetron Co-sputtering technique. Adv. Mater. Res. 2013, 770, 221-224.

25. Necula, B.S.; van Leeuwen, J.P.T.M.; Fratila-Apachitei, E.L.; Zaat, S.A.J.; Apachitei, I.; Duszczyk, J. In vitro cytotoxicity evaluation of porous $\mathrm{TiO}_{2}-\mathrm{Ag}$ antibacterial coatings for human fetal osteoblasts. Acta. Biomater. 2012, 8, 4191-4197.

26. Fu, G.; Vary, P.S.; Lin, C. Anatase $\mathrm{TiO}_{2}$ nanocomposites for antimicrobial coatings. J. Phys. Chem. B. 2005, 109, 8889-8898.

27. Choi, H.C.; Jung, Y.M.; Kim, S.B. Size effects in the Raman spectra of $\mathrm{TiO}_{2}$ nanoparticles. Vib. Spectrosc. 2005, 37, 33-38.

28. Seery, M.K.; George, R.; Floris, P.; Pillai, S.C. Silver doped titanium dioxide nanomaterials for enhanced visible light photocatalysis. J. Photochem. Photobiol. A Chem. 2007, 189, 258-263.

29. Jiang, Z.; Ouyang, Q.; Peng, B.; Zhang, Y.; Zan, L. Ag size-dependent visible-light-responsive photoactivity of $\mathrm{Ag}-\mathrm{TiO}_{2}$ nanostructure based on surface plasmon resonance. J. Mater. Chem. A 2014, 2, 19861-19866.

30. Ash, B.J.; Schadler, L.S.; Siegel, R.W. Glass transition behavior of alumina/polymethylmethacrylate nanocomposites. Mater. Lett. 2002, 5, 83-87. 
31. Fujishima, A.; Rao, T.N.; Tryk, D.A. Titanium dioxide photocatalysis. J. Photochem. Photobiol. A Photochem. Rev. 2000, 29, 1-21.

32. Verdier, T.; Coutand, M.; Bertron, A.; Roques, C. Antibacterial activity of $\mathrm{TiO}_{2}$ photocatalyst alone or in coatings on E. coli: The influence of methodological aspects. Coatings 2014, 4, 670-686.

33. Gogniat, G.; Thyssen, M.; Denis, M.; Pulgarin, C.; Dukan, S. The bactericidal effect of $\mathrm{TiO}_{2}$ photocatalysis involves adsorption onto catalyst and the loss of membrane integrity. FEMS Microbiol. Lett. 2006, 258, 18-24.

34. Yu, B.; Leung, K.M.; Guo, Q.; Lau, W.M.; Yang, J. Synthesis of Ag-TiO 2 composite nano thin film for antimicrobial application. Nanotechnology 2011, 22, doi:10.1088/0957-4484/22/11/115603.

35. Liu, Y.; Wang, X.; Yang, F.; Yang, X. Excellent antimicrobial properties of mesoporous anatase $\mathrm{TiO}_{2}$ and $\mathrm{Ag} / \mathrm{TiO}_{2}$ composite films. Microporous Mesoporous Mater. 2008, 114, 431-439.

36. Swetha, S.; Santhosh, S.M.; Geetha Balakrishna, R. Synthesis and comparative study of nano-TiO 2 over degussa P-25 in disinfection of water. Photochem. Photobiol. 2010, 86, 628-632.

37. Dodd, N.J.F.; Jha, A.N. Photoexcitation of aqueous suspensions of titanium dioxide nanoparticles: An electron spin resonance spin trapping study of potentially oxidative reactions. Photochem. Photobiol. 2011, 87, 632-640.

38. Gabriel, M.M.; Mayo, M.S.; May, L.L.; Simmons, R.B.; Ahearn, D.G. In vitro evaluation of the efficacy of a silver-coated catheter. Curr. Microbiol. 1996, 33, 1-5.

39. Van Hullebusch, E.D.; Zandvoort, M.H.; Lens, P.N.L. Metal immobilisation by biofilms: Mechanisms and analytical tools. Rev. Environ. Sci. Biotechnol. 2003, 2, 9-33.

40. Slawson, R.M.; Vandyke, M.I.; Lee, H.; Trevors, J.T. Germanium and silver resistance, accumulation, and toxicity in microorganisms. Plasmid 1992, 27, 72-79.

41. Akhavan, O.; Ghaderi, E. Self-accumulated Ag nanoparticles on mesoporous $\mathrm{TiO}_{2}$ thin film with high bactericidal activities. Surf. Coat Technol. 2010, 204, 3676-3683.

42. Kubacka, A.; Ferrer, M.; Cerrada, M.L.; Serrano, C.; Sanchez-Chaves, M.; Fernandez-Garci, M.; de Andres, A.; Rioboo, R.J.J.; Fernandez-Martin, F.; Fernandez-Garcia, M. Boosting TiO 2 -anatase antimicrobial activity: Polymer-oxide thin films. Appl. Catal. B Environ. 2009, 89, 441-447.

43. Jansen, B.; Kohnen, W. Prevention of biofilm formation by polymer modification. J. Ind. Microbiol. 1995, 15, 391-396.

44. Jiang, H.; Manolache, S.; Wong, A.C.L.; Denes, F.S. Plasma-enhanced deposition of silver nanoparticles onto polymer and metal surfaces for the generation of antimicrobial characteristics. J. Appl. Polym. Sci. 2004, 93, 1411-1422.

45. Pant, R.R.; Buckley, J.L.; Fulmer, P.A.; Wynne, J.H.; McCluskey, D.M.; Phillips, J.P. Hybrid siloxane epoxy coatings containing quaternary ammonium moieties. J. Appl. Polym. Sci. 2008, 110, 3080-3086.

46. Park, E.-S.; Lee, H.-J.; Park, H.Y.; Kim, M.-N.; Chung, K.-H.; Yoon, J.-S. Antifungal effect of carbendazim supported on poly(ethylene-co-vinyl alcohol) and epoxy resin. J. Appl. Polym. Sci. 2001, 80, 728-736.

47. Necula, B.S.; Fratila-Apachitei, L.E.; Zaat, S.A.J.; Apachitei, I.; Duszczyk, J. In vitro antibacterial activity of porous $\mathrm{TiO}_{2}-\mathrm{Ag}$ composite layers against methicillin-resistant Staphylococcus aureus. Acta. Biomater. 2009, 2, 3570-3580. 
48. Jamuna-Thevi, K.; Bakar, S.A.; Ibrahim, S.; Shahab, N.; Toff, M.R.M. Quantification of silver ion release, in vitro cytotoxicity and antibacterialproperties of nanostuctured $\mathrm{Ag}$ doped $\mathrm{TiO}_{2}$ coatings on stainless steel deposited by RF magnetron sputtering. Vacuum 2011, 86, 235-241.

49. Balamurugan, A.; Balossier, G.; Laurent-Maquin, D.; Pina, S.; Rebelo, A.H.S.; Faure, J.; Ferreira, J.M.F. An in vitro biological and anti-bacterial study on a sol-gel derived silver-incorporated bioglass system. Dent. Mater. 2008, 24, 1343-1351.

50. Sun, S.-Q.; Sun, B.; Zhang, W.; Wang, D. Preparation and antibacterial activity of Ag-TiO 2 composite film by liquid phase deposition (LPD) method. Bull. Mater. Sci. 2008, 31, 61-66.

51. Akhavan, O. Lasting antibacterial activities of $\mathrm{Ag}-\mathrm{TiO}_{2} / \mathrm{Ag} / \mathrm{a}-\mathrm{TiO}_{2}$ nanocomposite thin film photocatalysts under solar light irradiation. J. Colloid. Interface Sci. 2009, 336, 117-124.

52. Kubacka, A.; Cerrada, M.L.; Serrano, C.; Fernández-García, M.; Ferrer, M.; Fernández-Garcia, M. Plasmonic nanoparticle/polymer nanocomposites with enhanced photocatalytic antimicrobial properties. J. Phys. Chem. C 2009, 113, 9182-9190.

53. Jung, W.K.; Koo, H.C.; Kim, K.W.; Shin, S.; Kim, S.H.; Park, Y.H. Antibacterial activity and mechanism of action of the silver ion in Staphylococcus aureus and Escherichia coli. Appl. Environ. Microbiol. 2008, 74, 2171-2718.

(C) 2015 by the authors; licensee MDPI, Basel, Switzerland. This article is an open access article distributed under the terms and conditions of the Creative Commons Attribution license (http://creativecommons.org/licenses/by/4.0/). 